\title{
DIFFERENTIATION AND GENETIC STRUCTURE OF Sclerophoma pythiophila (CORDA) V. HOEHN. STRAINS ASSOCIATED WITH VARIOUS DAMAGE AND DISEASE SYMPTOMS ON Pinus sylvestris L.
}

\author{
Wojciech Kraj, Tadeusz Kowalski, Marcin Zarek \\ Department of Forest Pathology, Agricultural University, Al. 29-Listopada 46, 31-425 Cracow, Poland \\ e-mail: rlkraj@cyf-kr.edu.pl
}

Received: 17.07.2008

\section{Abstract}

Eighty-three strains of Sclerophoma pythiophila were isolated in the period between 1996 and 2006 from needles and shoots of Pinus sylvestris displaying various types of disease symptoms or damages caused by Contarinia baeri or Thecodiplosis brachyntera. On the basis of fifty-six RAMS markers, very high genetic variability of examined strains was ascertained (mean value of Jaccard's coefficient 0.58 ). The highest genetic similarity was shown by strains related with needles damaged by Contarinia baeri (0.65), whereas the lowest by those derived from dead shoot tips (0.53). No monomorphic markers were found for individual groups of strains, yet on the basis of Nei's genetic distance matrix, it was possible to determine a group of closely related fungus populations which was connected with the damaging of the needles by C. baeri or T. brachyntera (Nei's coefficient ranging from 0.035 to 0.059 ) and populations related with the occurrence of necrosis on shoots or decay of their tips (Nei's coefficient - 0.066). The PCA confirmed genetic similarity of strains related with damaging of the needles by insects and strains isolated from local necroses on shoots and withered shoot tips. A high level of genetic variability between populations was shown by AMOVA analysis. A high level (14.9\%) and statistically significant $(\mathrm{P}=0.001)$ share of between-population genetic variability were ascertained.

Key words: Sclerophoma pythiophila, Contarinia baeri, Thecodiplosis brachyntera, RAMS

\section{INTRODUCTION}

Sclerophoma pythiophila (Corda) v. Hoehn. is a coelomycetous fungus, common in Europe, Northern America and other continents on over twenty species of pine trees, as well as the conifer genus Calocedrus, Cupressus, Picea, Abies, Larix, Thuja, Tsuga, Pseudotsuga and Juniperus (S utton and W aterston, 1970; Funk, 1985). It occurs in a number of varied relations to these plants. It is a common species in the phyllosphere of Scots pine and Norway spruce needles (Magan et al. 1995). It often populates live symptomless needles and shoots of pines and other conifers as an endophyte (Petrini et al. 1989, Kowalski and Kehr, 1992; Kowalski and Poździk, 1993; Kowalski and Stańczykiewicz, 2000). It is a saprotroph and a colonist of moribund needles, twigs and stems (S inclair and Lyon, 2005). It prefers needles rich in carbohydrates, hence it occurs more often on the needles of felled trees rather than on needles naturally fallen down being poor in these substances (Gre m me n, 1957; K ow a l s k i, 1988). It populates pine branches decaying in the lower part of the crown due to the lack of light, contributing to their natural thinning (Butin and Kowalski, 1990). The infected wood becomes grey-livid in colour; therefore $S$. pythiophila is included in the fungus group causing discolouration of wood (B u t in, 1965).

S. pythiophila often occurs as a weak facultative parasite which occasionally causes serious damage of trees under stress ( $\mathrm{F} \mathrm{u} \mathrm{n} \mathrm{k,} \mathrm{1985).} \mathrm{Its} \mathrm{pathogenic}$ properties were confirmed by experiments ( $\mathrm{S}$ m e r l is, 1970). K ow a ls ki (1983) often observed this species in live needles of Pinus sylvestris L. within the range of infectious stains, whereas Mańka and Przezbórski (1982) in connection with autumnal needlecast. With respect to shoots, it is believed to cause symptoms similar to those that are caused on coniferous trees by the Phomopsis type fungus ( $\mathrm{S}$ i n c l a i r and L y o n, 2005). Pre-disposing factors are primarily drought, low temperature and industrial emissions (K e it e 1, 1953; Jahnel and Junghans, 1957; Gibson, 1978; Kowalski and Domański, 1983). S. pythiophila secondarily overcomes trees infected by dangerous pathogens, e.g. Gremmeniella abietina (Lagerb.) Morelet on pines (Kowalski and Domański, 1983), Encoeliopsis laricina (Ettl.) Groves on tama- 
rack and Pseudophacidium piceae E. Mueller on black and white spruce (S merlis , 1970). The fungus is often associated with needle necrosis and shoot dieback on conifers that have sustained insect or mite attack (G ibs o n, 1978). With respect to Abies balsamea, it occurred as a dominant coloniser on needles attacked by Paradiplosis tumifex Gagne (P e tri n i et al. 1989). With respect to pines, the best known is the phenomenon of colonisation of needles damaged by Contarinia baeri (Prell) (B atko et al. 1958). It also occurs on needles and shoots of pines populated by needle gall midge Thecodiplosis brachyntera Schwaeg. (K o w a 1 $\mathrm{ski}, 1998)$. Differences in the possibility of causing illness and the type of symptoms caused may result not only from varied predispositions of the host plants, but also from genetic variability within the range of a given fungus population occurring in a given area. This situation was ascertained with respect to the number of fungi causing diseases of forest trees, e.g. Grem- meniella abietina, Sirococcus conigenus (DC.) Cannon and Minter, Sphaeropsis sapinea (Fr.:Fr.) D y k o and $\mathrm{S}$ utt on, Botrytis cinerea Pers.:Fr. (de W et et al. 2003; U otil a et al. 2006; R os s m a n et al. 2008).

Due to the lack of such research both in Poland and in other countries in relation to $S$. pythiophila, research was undertaken with respect to genetic variability between the populations of this fungus isolated from needles and shoots of Pinus sylvestris displaying various types of damages and disease symptoms.

\section{MATERIALS AND METHODS}

Isolates

Eighty-three strains of $S$. pythiophila isolated during the period from 1996 to 2006 from three to ten year old $P$. sylvestris L. were used in this study. They came from eleven Forest Districts located in northern and southern Poland (Tab. 1) where S. pythiophila

Table 1

Origin of Sclerophoma pythiophila isolates examined.

\begin{tabular}{|c|c|c|c|}
\hline Kind of damages & For. District & Coordinates & Strain No. \\
\hline \multirow[b]{2}{*}{$\begin{array}{l}\text { Needles damaged } \\
\text { by Contarinia baeri (CB) }\end{array}$} & Brynek & $50^{\circ} 31^{\prime}, 18^{\circ} 44^{\prime}$ & $16525 / 2,17068 \mathrm{a}, 17068 \mathrm{~b}, 17069,17070$ \\
\hline & Swierklaniec & $50^{\circ} 26^{\prime}, 18^{\circ} 56^{\prime}$ & $\begin{array}{l}\text { 18387, 18385, 18386, 18388, 18389, 18390, 18391, 18392, } \\
\text { 18393, 18394, 18395, 18396, 18397, 18398, 18399, 18403, } \\
18405,18406,18408,18416,18417,18419\end{array}$ \\
\hline \multirow{4}{*}{$\begin{array}{l}\text { Thecodiplosis brachyntera } \\
\text { - moribund needles, } \\
\text { shortened (TB1) }\end{array}$} & Rytel & $53^{\circ} 45^{\prime}, 17^{\circ} 46^{\prime}$ & S 311/1, S 772, S 772/1 \\
\hline & Osie & $53^{\circ} 35^{\prime}, 18^{\circ} 20^{\prime}$ & $\begin{array}{l}\text { S } 258 / 2, \text { S } 258 / 3, \text { S } 258 / 4, \text { S } 259 / 5, \text { S } 311, \text { S } 311 / 2 \text {, } \\
\text { S 474/1, S 474/2 }\end{array}$ \\
\hline & Przymuszewo & $53^{\circ} 33^{\prime}, 17^{\circ} 39^{\prime}$ & S 328/1, S 389/1, S 393/3 \\
\hline & Szczecinek & $53^{\circ} 42^{\prime}, 16^{\circ} 42^{\prime}$ & S $654 / 2$ \\
\hline \multirow{3}{*}{$\begin{array}{l}\text { Thecodiplosis brachyntera } \\
\text { - yellow or brown needles, } \\
\text { un-shortened (TB2) }\end{array}$} & Lubichowo & $53^{\circ} 51^{\prime}, 18^{\circ} 24^{\prime}$ & S 599b/4, S 600b/1, S 647b/1, S 648b/5 \\
\hline & Osie & $53^{\circ} 35^{\prime}, 18^{\circ} 20^{\prime}$ & S 229/5, S 240/2, S 288/2, S 294/1, S 294/2, S 295/2 \\
\hline & Rytel & $53^{\circ} 45^{\prime}, 17^{\circ} 46^{\prime}$ & S 786/1, S 786/2 \\
\hline \multirow{3}{*}{$\begin{array}{l}\text { Shoot necroses in the place } \\
\text { of location of needles marked } \\
\text { by } T \text {. brachyntera }(\mathrm{TB} 3)\end{array}$} & Niedzwiady & $53^{\circ} 47^{\prime}, 17^{\circ} 15^{\prime}$ & $16415 / 1$, S $687 / 3$, S 688/5, S 690, S 690/2, S 732/4, S 732/2 \\
\hline & Osie & $53^{\circ} 35^{\prime}, 18^{\circ} 20^{\prime}$ & $\begin{array}{l}\text { S 458/1, S 461/1, S 462/5, } \\
\text { S 489/3, S 490/4 }\end{array}$ \\
\hline & Miastko & $53^{\circ} 59^{\prime}, 16^{\circ} 57^{\prime}$ & S 661/1, S 662/2, S 662/3, S 663/1, S 663/3, S 663/4, S 668/1 \\
\hline \multirow{4}{*}{ Dead shoot tips (DS) } & Kaliska & $53^{\circ} 54^{\prime}, 18^{\circ} 13^{\prime}$ & S 836 \\
\hline & Lubichowo & $53^{\circ} 51^{\prime}, 18^{\circ} 24^{\prime}$ & S 808b, \\
\hline & Okonek & $53^{\circ} 31^{\prime}, 16^{\circ} 50^{\prime}$ & S 891a, S 890a, S 890b, \\
\hline & Niedzwiady & $53^{\circ} 47^{\prime}, 17^{\circ} 15^{\prime}$ & S 913, S 914, S 915, S 917, S 918 \\
\hline
\end{tabular}


Table 2

Primer used, number of amplified products and range of their length (bp).

\begin{tabular}{cccccc}
\hline Lp. & $\begin{array}{c}\text { Primer } \\
\text { name }\end{array}$ & Sequence $\left(5^{\prime} \rightarrow 3^{\prime}\right)$ & $\begin{array}{c}\text { Temperature of } \\
\text { annealing }\left[{ }^{\circ} \mathrm{C}\right]\end{array}$ & $\begin{array}{c}\text { Number of } \\
\text { amplified } \\
\text { products }\end{array}$ & $\begin{array}{c}\text { Length of } \\
\text { obtained } \\
\text { products [bp] }\end{array}$ \\
\hline 1 & AGC & DHBAGCAGCAGCAGCAGC & 60 & 11 & $233-723$ \\
\hline 2 & AGT & DHBAGTAGTAGTAGTAGT & 30 & 11 & $374-1404$ \\
\hline 3 & CGA & DHBCGACGACGACGACGA & 61 & 10 & $285-1500$ \\
\hline 4 & CT7 & DYDCTCTCTCTCTCTCT & 41 & 12 & $318-1321$ \\
\hline 5 & GT7 & DYDGTGTGTGTGTGTGT & 53 & 12 & $308-1500$
\end{tabular}

were associated with disease symptoms or insect damages. One group constituted strains isolated from needles damaged by Contarinia baeri (CB). These were moribund, browned needles of normal length (not shortened) and bent downwards at the base in a characteristic manner (Fig. 1). The second group constituted isolates from needles and shoots displaying decay symptoms as a result of damage of needles by $T$. brachyntera. These were: a) moribund needles, shortened (to approx. 30\% of normal length), with a clearly thickened base part (TB1) (Fig. 2), b) unshortened moribund needles which grew within the range of necrosis of shoots accompanying the needles damaged by T. brachyntera (TB2) (Fig. 3), and c) necroses on shoots in the place of location of needles marked by $T$. brachyntera (TB3). The third group constituted isolates from dead shoot tips (DS) (Tab. 1). Damages caused by $T$. brachyntera were often accompanied by the colonisation by Cenangium ferruginosum Fr. (K o w al s k i, 1998).

From each sample, between 6 and 12 fragments of shoots or the same amount of fragments from needles were collected. After surface sterilisation of samples (1 min. ethanol 96\%, 5 min. $\mathrm{NaOCl} 4 \%, 30 \mathrm{sec}$. ethanol 96\%) and removing surface bark, pieces of shoots 5 × 2 × $2 \mathrm{~mm}$ were removed (in the case of needles, these were pieces $5 \mathrm{~mm}$ long) and placed in Petri dishes on the surface of $2 \%$ malt extract (MEA; $20 \mathrm{~g} \times \mathrm{l}^{-1}$ malt extract Difco, Sparks, MD, USA, $15 \mathrm{~g} \times \mathrm{l}^{-1}$ agar Difco supplemented with $100 \mathrm{mg} \times \mathrm{l}^{-1}$ streptomycin sulphate). One colony of $S$. pythiophila was randomly selected and subcultured on the medium.

\section{Molecular analysis}

Genomic DNA was extracted with the use of the DNeasy Plant Mini Kit (Qiagen). Genetic variability of S. pythiophila strains was determined with the use of RAMS (Random Amplified Microsatellites) meth- od (Zie tki e w i c z et al. 1994). For the PCR reaction, five primers were used (Tab. 2). DNA amplification of fungus was conducted in $10 \mu \mathrm{l}$ of reactive mixture comprising: PCR buffer, $\mathrm{MgCl}_{2} 1 \mathrm{mM}$, dNTP 200 $\mathrm{mM}$ (Fermentas), primer $1 \mu \mathrm{M}$, Taq DNA polymerase $0.2 \mathrm{U}$ (Qiagen), DNA $10 \mathrm{ng}$.

The PCR reaction was done according to the following programme in a thermocycler Biometra T3: initial denaturation $-95^{\circ} \mathrm{C}$ for 5 minutes, then 36 cycles, where every cycle contained the following steps: denaturation at a temperature of $95^{\circ} \mathrm{C}$ for 1 minute, annealing for 45 seconds in various temperatures depending on the primer (Tab. 2), elongation at $72^{\circ} \mathrm{C}$ for 2.5 minutes. Elongation of the last cycle was extended to 8 minutes. Each amplification reaction was conducted twice in order to check the repeatability of occurrence of electrophoretic profiles.

Products of DNA amplification were resolved in $1.5 \%$ agarose gel (Agarose Basica LE, Prona) with the addition of $0.2 \mu \mathrm{g} \times \mathrm{ml}^{-1}$ ethidium bromide in TBE buffer. A GeneRuler 100 bp Ladder Plus (Fermentas) was used as a marker of the length of DNA fragments. The electrophoresis was conducted at $2 \mathrm{~V} \times \mathrm{cm}^{-1}$ for 2-3 hours. The image of the electrophoresis was then produced employing a documentation set of electrophoretic gels by Vilber Laurmat. The lengths of amplified products were determined using BIO $1 \mathrm{D}++$ software (Vilber Lourmat).

\section{Statistical analysis}

Each RAMS marker was scored as present (1) or absent (0). Binary data was used to calculate Jaccard's genetic similarity coefficient between strain pairs and to prepare a matrix of genetic similarity.

In order to determine the genetic structure of the examined strains with the use of the programme GeneAlEx 6.0, molecular variance analysis (AMOVA) was conducted for the strain groups (populations) related 
Table 3

Band patterns across groups of strains associated with insect damages caused by Contarinia baeri and Thecodiplosis brachyntera and strains isolated from dead shoot tips (Notations of types of damages like in Table 1).

\begin{tabular}{lccccc}
\hline Kind of damages & $\begin{array}{c}\text { Number of } \\
\text { strains }\end{array}$ & $\begin{array}{c}\text { No. } \\
\text { of bands }\end{array}$ & $\begin{array}{c}\text { No. } \\
\text { of monomorphic } \\
\text { bands }\end{array}$ & $\begin{array}{c}\text { Jaccard's } \\
\text { coefficient }\end{array}$ & $\begin{array}{c}\% \text { of } \\
\text { polymorphic } \\
\text { loci }\end{array}$ \\
\hline CB & 27 & 50 & 1 & 0.65 & 78.6 \\
\hline TB1 & 15 & 47 & 5 & 0.55 & 69.6 \\
\hline TB2 & 12 & 35 & 1 & 0.57 & 51.8 \\
\hline TB3 & 19 & 42 & 1 & 0.59 & 64.2 \\
\hline DS & 10 & 46 & 0 & 0.53 & 75.0 \\
\hline
\end{tabular}

Table 4

Analysis of molecular variance (AMOVA) for groups of strains of $S$. pythiophila associated with insect damages caused by Contarinia baeri and Thecodiplosis brachyntera, and isolated from dead shoot tip conducted using 56 RAMS alleles.

\begin{tabular}{lcccccc}
\hline \multicolumn{1}{c}{ Source of variation } & df & $\begin{array}{c}\text { Sum of } \\
\text { squares }\end{array}$ & Variance & $\begin{array}{c}\text { \% Total } \\
\text { variance }\end{array}$ & $\Phi$ & P \\
\hline Among populations & 2 & 64,668 & 1,098 & 14,93 & & \\
\hline Within populations & 80 & 500,224 & 6,253 & 85,07 & 0,149 & 0.001 \\
\hline Total & 82 & 564,892 & 7,351 & & & \\
\hline
\end{tabular}

Table 5

Matrix of Nei's standard genetic distance among groups of strains of $S$. pythiophila associated with insect damages caused by Contarinia baeri and Thecodiplosis brachyntera, and isolated from dead shoot tips

(Notations of types of damages like in Table 1).

\begin{tabular}{lccccc}
\hline Symptomy & CB & TB1 & TB2 & TB3 & DS \\
\hline CB & 0.000 & & & & \\
\hline TB1 & 0.059 & 0.000 & & & \\
\hline TB2 & 0.045 & 0.035 & 0.000 & & \\
\hline TB3 & 0.108 & 0.074 & 0.079 & 0.000 & \\
\hline DS & 0.090 & 0.110 & 0.148 & 0.066 & 0.000 \\
\hline
\end{tabular}

with the occurrence of damages caused by Contarinia baerii and Thecodiplosis brachyntera and isolated from moribund shoot tips (Peakall and S mouse, 2006; E x c offier et al. 1992). Variance components are expressed as the percentage of total variance, where statistical significance of components was tested with the use of 1,000 permutations.

Genetic distance between the examined strain groups was expressed with the use of Nei's standard genetic distance (N e i, 1972; E x c o f fi e r et al. 1992). To represent geometric relationships among groups of strains, a Principal Component Analysis (PCA) via a covariance matrix with data standardisation was ap- plied in GenAlEx 6.0 using the genetic distances between strains calculated according to the method described by $\mathrm{Huff}$ et al. (1993). Scatter diagrams were examined to visualize geometric relationships between strains.

On the basis of Jaccard's coefficients, analysis of within-population genetic variability of fungus was conducted for strain pairs. In order to show statistical differences with respect to within-population variability of strains with the use of programme Statistica 7.1 (Statsoft Inc.), ANOVA analysis was conducted. 


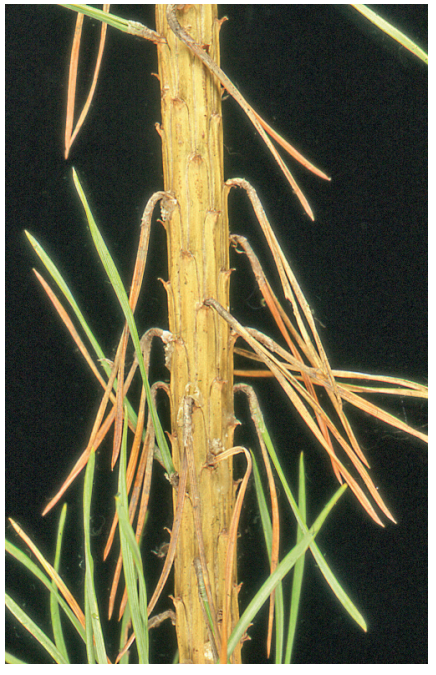

Fig. 1. Pine shoot with needles damaged by Contarinia baeri (characteristic basal collapse of affected needles).

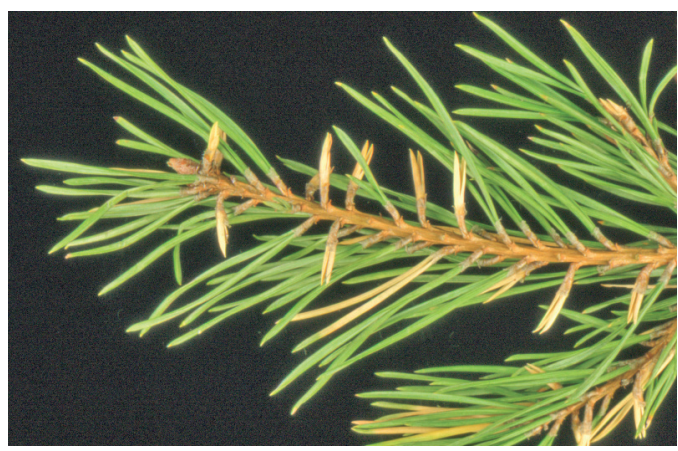

Fig. 2. Pine shoot with needles damaged by Thecodiplosis brachyntera (characteristic shortened needles with clearly thickened base part).

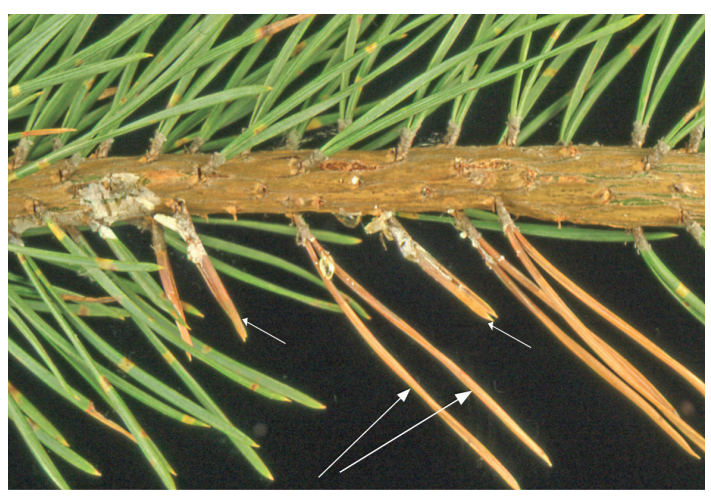

Fig. 3. Moribund, shortened needles damaged by Thecodiplosis brachyntera (short arrows), and un-shortened needles (long arrows) which grew within the range of necrosis of shoots.

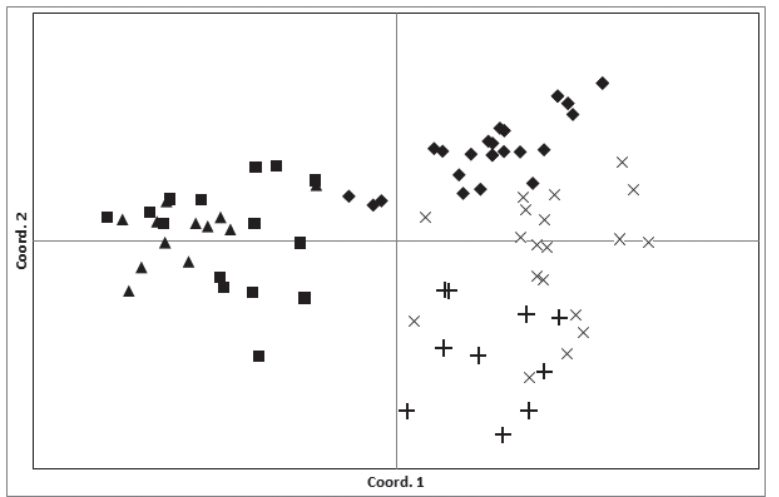

Fig 4. Principal Component Analysis (PCA) for S. pythiophila strains via matrix of genetic distance between individuals deriving from individual regions of Poland. Projection into $1^{\text {st }}$ and $2^{\text {nd }}$ coordinate. Percentage of variability explained by the first two axes: $30.19 \%$ and $19.99 \%$. Markers: $\checkmark-\mathrm{CB}, \boldsymbol{\square}-\mathrm{TB} 1, \boldsymbol{\Delta}-\mathrm{TB} 2, \times-\mathrm{TB} 3,+-\mathrm{DS}$.

\section{RESULTS}

In total, fifty-six RAMS markers were obtained. The number of products of PCR reaction for the applied primers was similar and it varied from 10 to 12 . The length of obtained bands varied from 200 to 1,500 nucleotides, with the exception of the AGC primer for which it varied from 233 to 723 nucleotides (Tab. 2). Out of fifty-six markers, only two (GT7_1500 bp and GT7_996 bp) were fully monomorphic for all the examined strains, whereas seven (CT7_719, AGC_433, CGA_1500,CGA_1003, CGA_839, CGA_420, AGT_ 748) were monomorphic in a degree above $90 \%$.

Depending on the examined group of strains, varied numbers of RAMS markers were obtained; the highest number was obtained for the strains related with the occurrence of Contarinia baeri (50 markers) (Tab. 3). The examined strains were characterised by very high within-population genetic variability. The average value of Jaccard's coefficient amounted to 0.58 , whereas the differentiated strain groups were statistically different (with $\mathrm{P}<0.01$ ) with respect to the value of this coefficient. Isolates related with the occurrence of Contarinia baeri (Jaccard's coefficient 0.65) were most similar, whereas the lowest genetic similarity was displayed by the strains deriving from moribund shoot tips (0.53). It was ascertained that the number of monomorphic markers was slight in reference to individual groups of strains. None of them was characteristic for strains related with a specific type of symptoms (Tab. 3).

Between-population strain variability was expressed with the use of Nei's genetic distance. On the basis of the value of Nei's coefficients, two groups of populations were distinguished: the first compris- 
ing three populations isolated from needles damaged by Contarinia baeri and Thecodiplosis brachyntera (CB, TB1, TB2) and the second comprising strains deriving from local necroses on shoots damaged by T. brachyntera (TB3) and strains isolated from shoot tips displaying symptoms of withering (DS). It was found that genetic distance between population pairs related with damages of needles by insects was slight and varied from 0.035 to 0.059 . Slightly higher genetic distance was observed between groups of strains isolated from necroses on shoots and moribund shoot tips (Nei's coefficient 0.066). Genetic distances among populations deriving from the two differentiated groups of populations were much larger and amounted from 0.074 to 0.148 (Tab. 5).

The results of AMOVA indicated that the variance components expressed as percentages of the total variation among and within groups of strains associated with disease symptoms or insect damages were $14.9 \%$ and $85.1 \%$, respectively. The random permutation test revealed that variance components were highly significant $(\mathrm{P}=0.001)$ and indicated a high degree of genetic differentiation among groups of strains (Tab. 4).

For the purpose of graphic presentation of variability of the examined fungus population, Principal Component Analysis (PCA) was conducted. It largely confirmed the results from Nei's genetic distance matrix. A close relationship was revealed between the groups of strains associated with needle damages caused by $T$. brachyntera (TB1, TB2) and between the group of strains isolated from necroses (TB3) and tips of dead shoots (DS) (Fig. 4).

\section{DISCUSSION}

The research in recent years indicates that the number of fungi previously identified as species should be recognised as species complexes consisting of a cluster of closely related species difficult to distinguish on the basis of morphological criteria (R os s$\mathrm{m}$ an et al. 2008). Individual species comprising this complex may often be differentiated only with the use of methods based on examination of their biochemical properties (e.g. profile of fatty acids and sterols, pectin enzymes) or DNA sequence analysis. Within the scope of strains included within one species, the phenomenon of varied virulence may occur and cause different disease symptoms or preferences, depending on the host plant. As a result of methodologically varied research, within a given species morphological groups or types are distinguished first, then inter-sterile groups, phyllo-genetic groups, and in the course of time - separate species. This situation took place in the case of two most dangerous causes of forest tree diseases: Armil- laria mellea (Vahl) Kumm. s. 1. and Heterobasidion annosum (Fr.) Bref. s. 1.; similar determinations have recently been made with respect to the number of other species of pathogenic fungi. For example, within the scope of Gremmeniella abietina in Scandinavia, LTT type (large tree type) was distinguished which appears to be more pathogenic and causes damage to all sizes of pine trees and STT type (small tree type), and which kills seedlings smaller than $2 \mathrm{~m}$ in regions with thick snow cover in winter (Uotila et al. 2006). With the use of RAMS markers, both types were also found in Poland (Kraj and Kowalski, 2008). On the basis of RFLP analyses of sequences of ribosomal (ITS1 - 5.8 S - ITS2) and mitochondrial DNA, it was also shown that strains infecting various species of pines in Poland are characterised by greater specificity in relation to the host plant than in relation to the place of their origin (K r a j, 2009). Within the range of Sphaeropsis sapinea, three morphotypes were distinguished $-\mathrm{A}, \mathrm{B}$ and $\mathrm{C}-$ which differ in pathogenicity. The B morphotype was recently distinguished as a new discrete taxon and described as Diplodia scrobiculata J. de Wet, B. Slippers \& M. J. Wingfield (de W et et al. 2003). Within the range of Sirococcus conigenus, which has been recorded for over 200 years on needles, shoots, cones and seeds of various coniferous species, first three forms were distinguished on the basis of morphological and genetic features (marked as $\mathrm{S}$, $\mathrm{P}$ and $\mathrm{T}$ groups), which were subsequently identified as $S$. conigenus s. str. and two separate new species S. piceicola Rossman et al. and S. tsugae Rossman et al. (R o s s m a n et al. 2008).

Current research has shown that large genetic variability also occurs with respect to Sclerophoma pythiophila among strains accompanying various types of symptoms and damages on needles and shoots of Pinus sylvestris. This is demonstrated by the high number (comparable with other fungi species) of obtained markers and the percentage share of polymorphic loci, as well as low values of Jaccard's coefficient. This is even more significant due to the fact that in Poland no teleomorph stage has been observed so far, and in the neighbouring countries it is quite rare (B u t in, 1964; S merlis, 1970; Kowalski, 1988). The sources of genetic variability such as mutations, somatic hybrydisation and hetero-karyosis with respect to a number of fungi reproducing asexually or with a low share of sexual reproduction, are little known (B urdon and Silk, 1997; B ock et al. 2002), despite the fact that its level can be typical of the sexual system (Gu o et al. 2004).

The research did not allow for obtaining monomorphic markers characteristic for the examined populations, thanks to which it would be possible to identify strains. Despite the fact that AMOVA was originally 
performed for other types of molecular data, it has been widely used to analyse RAMS data ( $\mathrm{Huff}$ et al. 1993). It displayed the existence of clear statistically significant differences between the examined groups of strains of $S$. pythiophila. The analysis of the matrix of Nei's genetic distance between individual populations and the absence of monomorphic markers allows for surmising that the reason for genetic variability of the population were differences in the distribution of frequencies of occurrence of RAMS markers distributed over the entire genome of the examined populations. The graphic image of between-population relations among strains confirms the existence of differentiated groups of strains related with specific types of damages of pine needles and shoots.

The reasons for the existence of above interdependencies ascertained by molecular examination may have different grounds. S. pythiophila occurs commonly as a saprotroph on dead vegetal substrate (Gre m me n , 1960; Kow alski, 1988). On this substratum, conidia in pycnidial conidiomata are produced in large numbers, which constitute the main inoculum reservoir. According to Butin's research (1965), it follows that they are distributed over small distances and the highest concentration of spores is ascertained in the region of their origin, which takes place mainly in pine stands. If the pines are damaged by biotic or abiotic factors, trees under the impact of stress will be subject to the impact of this inoculum.

On the other hand, S. pythiophila may occur as an endophyte in live symptomless needles and shoots of pine and other coniferous trees (Petrini et al. 1989; Kowalski and Kehr, 1992; Kowalski, 1993; Kowalski and Poździk, 1993; Kowalski and Stańczykiewicz, 2000). It is probable that only certain physiological fungus forms are adjusted to this form of life, characterised by the ability to produce appropriate substances (de Hoog and Y urlova, 1994; B rzezow s ka et al. 2005). In the case of damage of shoots and needles, these strains occurring endophytically may have a greater chance for colonising the tissue than the ones that are infecting from "the outside."

S. pythiophila often occurs on Pinus sylvestris needles damaged by such insects as Contarinia baeri and Thecodiplosis brachyntera (B at ko et al. 1958; K ow alski, 1998; S i e r o ta et al. 1998). However, it has not been ascertained if such insects may carry spores or hyphae fragments of this fungus species. They may potentially exert an impact with respect to which strains of $S$. pythiophila colonise needles through the period of damaging the pine needles. The biology of these two species of insects shows that $T$. brachyntera damages needles earliest. This usually takes place in May, when the needles are $4-7 \mathrm{~mm}$ long. The larvae induce the creation of outgrowths at the needle base and hinder needle elongation (S c h w e $\mathrm{nke}, 1982$ ).

In the regions where the teleomorph stage of S. pythiophila occurs (known as Sydowia polyspora (Bref. Et v. Tav.) Müller), infections of needles damaged by $T$. brachyntera may be caused by ascospores due to the fact that fruiting bodies of $S$. polyspora mature in spring (M u n k, 1957).

The obtained results justify further research on genetic variability of $S$. pythiophila strains accompanying various types of disease symptoms and damages on pine shoots and needles with the use of different molecular methods. In the research on variability of Sphaeropsis sapinea morphotypes, only the application of multiple gene genealogies and microsatellite markers allowed for determining the relationship between these morphotypes and distinguishing a new species (de Wet et al. 2003).

\section{Acknowledgments}

This study was financially supported by The Polish Committee for Scientific Research, grant no. 2 P06L 07629

\section{REFERENCES}

B atk o S., Murray J. S., Peace T. R., 1958. Sclerophoma pythiophila associated with needle-cast of pines and its connexion with Pullularia pullulans. Trans. Brit. Mycol. Soc. 41: 126-128.

B ock C. H., Thrall P. H., B rubaker C. L., B urdon J. J., 2002. Detection of genetic variation in Alternaria brassicicola using AFLP fingerprinting. Mycol. Res. 106: 428-434.

Brzezowska E., D mochowska-Gładys z J., Kowalski T., 2005. Abilities of Sclerophoma pythiophila and Epithyrium resinae cultures to transform steroid hormones and their esters. Acta Scientiarum Polonorum, Biotechnologia, 4: 13-19.

B urd on J. J., Silk J., 1997. Sources and patterns of diversity in plant-pathogenic fungi. Phytopathology, 87: 664669.

B ut in H., 1964. Über zwei Nebenfruchtformen von Sydowia polyspora (Bref. et v. Tav.) Müller. Sydowia, 17: 114118.

B u t in H., 1965. Untersuchungen zur Ökologie einiger Bläuepilze an verarbeitetem Kiefernholz. Flora, 155: 400440.

But in H., Kowalski T., 1990. Die natürliche Astreinigung und ihre biologischen Voraussetzungen. V. Die Pilzflora der Kiefer, Fichte und Lärche. Eur. J. For. Path. 20: 44-54.

Ex c offi er L., S m o u se P. E., Qu at tro J. M., 1992. Analysis of Molecular Variance Inferred From Metric Distances Among DNA Haplotypes: Application to Human 
Mitochondrial DNA Restriction Data. Genetics, 131: 479-491.

Fu n k A., 1985. Foliar fungi of western trees. Can. Forest Service Victoria: 159.

Gibs on I. A. S., 1978. Diseases of forest trees widely planted as exotics in the tropics and southern hemisphere. Part II. The genus Pinus. Commonw. Mycol. Inst., Kew, U.K.

Gremmen J., 1957. Microfungi decomposing organic remains of pines. Fungus, 27: 34-42.

Gremmen J., 1960. A contribution to the mycoflora of pine forest in the Netherlands. Nova Hedwigia, 1: 251-288.

Guo L. D., Li Xu., Zheng W. H., Hyde K. D., 2004. Genetic variation of Alternaria alternata, an endophytic fungus isolated from Pinus tabulaeformis as determined by random amplified microsatellites (RAMS). Fungal Divers. 16: 53-65.

Ho o g de G. S., Y u r lov a N. A., 1994. Conidiogenesis, nutritional physiology and taxonomy of Aureobasidion and Hormonema. Antonie van Leeuwenhoek, 65: 41-54.

Huff D. R., Peakall R., S mou se P. E., 1993. RAPD variation within and among natural populations of outcrossing buffalograss Buchloe dactyloides (Nutt) Engelm. Theor. Appl. Genet. 86: 927-934.

J ahne 1 H., J u ng han s B., 1957. Über eine wenig bekannte Kiefernkrankheit (Sclerophoma pityophila). Forstw. Cbl. 76: 129-192.

Ke itel B., 1953. Auftreten einer neuen Kiefernkrankheit. Der Wald S. 320.

Kowalski T., 1983. Fungi infecting Pinus sylvestris needles of various ages. Eur. J. For. Path. 12: 182-190.

Kowalski T., 1988. Zur Pilzflora toter Kiefernnadeln. Zeitschr. für Mykologie, 54: 159-173.

Kowalski T., 1993. Fungi in living symptomless needles of Pinus sylvestris with respect to some observed disease processes. J. Phytopathology, 139: 129-145.

Kowalski T., 1998. A study on Cenangium shoot dieback of Pinus sylvestris L. in Poland. In: „Disease/Environment Interactions in Forest Decline" (eds. T. L. Cech et al.). Proceedings of a Workshop of the Working Party Disease. / Environment Interactions in Forest Decline. IUFRO 7.02.06. Vienna, Austria, March, 16-21: 1998, 73-81.

Kowalski T., Domański S., 1983. Występowanie i przyczyny odwierzchołkowego zamierania pędów Pinus nigra, $P$. silvestris i $P$. strobus $\mathrm{w}$ niektórych drzewostanach południowej Polski w latach 1979-1980. / Occurence and source of the shoot top die-back of Pinus nigra, $P$. sylvestris and $P$. strobus in some forest stands in Southern Poland in 1979-1980. Acta Agr. Silv. Ser. Silv. 20: 19-34.

Kowalski T., Kehr R. D., 1992. Endophytic fungal colonization of branch bases in several forest tree species. Sydowia, 44: 137-168.

Kowalski T., Poździk P., 1993. Grzyby endofityczne w żywych igłach Pinus sylvestris L. / Endophytic fun- gi in living symptomless needles of Pinus sylvestris L. Acta Agr. Silv. ser. Silv. 31: 17-30.

Kowalski T., Stańczykiewicz A., 2000. Communities of endophytic fungi in twigs and needles of Pinus sylvestris affected to a different degree by air pollution. Phytopathol. Pol. 19: 69-87.

Kraj W., Kowalski T., 2008. Genetic variation of polish strains of Gremmeniella abietina. For. Pathol. 38: 203217.

Kraj W, 2009. Genetic polymorphism of Polish strains of Gremmeniella obietina and Bruchorstia pinea var. cembrae. Dendrobiology, 61: 13-21.

Magan N., Kirkwood I. A., McLeod A. R., S mith K., 1995. Effect of open-air fumigation with sulphur dioxide and ozone on phyllosphere and endophytic fungi of conifer needles. Plant Cell Environ. 18: 291-302.

Mańka K., Przezbórski A., 1982. Dalsze obserwacje związane z występowaniem w Polsce choroby igieł sosny powodowanej przez grzyb Sclerophoma pityophila (Corda) v. Höhn, / Further observations on the occurence of pine needle disease caused by the fungus Sclerophoma pityophila (Corda) Höhn in Poland, Sylwan, 126: 11-18.

Munk A., 1957. Danish Pyrenomycetes. Copenhagen.

Ne i M., 1972. Genetic distance between populations. American Naturalist, 106: 283-392.

Peakall R. O. D., S mou se P. E., 2006. Genalex 6: genetic analysis in Excel. Population genetic software for teaching and research. Mol. Ecol. Notes, 6: 288-295.

Petrini L., Petrini O., Laflamme G., 1989. Recovery of endophytes of Abies balsamea from needles and galls of Paradiplosis tumifex. Phytoprotection, 70: 97-103.

Rossman A. Y., Castlebury L. A., Farr D. F., Stanosz G. R., 2008. Sirococcus conigenus, Sirococcus piceicola sp. nov. and Sirococcus tsugae sp. nov. on conifers: anamorphic fungi in the Gnomoniaceae, Diaporthales. Forest Pathol. 38: 47-60.

Schwenke W., 1982. Die Forstschädlinge Europas. Verlag Paul Parey Hamburg und Berlin.

Sierota Z., Kolk A., Ślusarski S., 1998. Przyczyny i przebieg zjawiska zamierania pędów sosny zwyczajnej na terenie północno-zachodniej części Polski w latach 1995-1997. / The cause and course of the shoot tip dieback of Scots Pine in the northwestern part of Poland in the period of 1995-1997. Prace IBL, seria B, 34: 7593.

Sinclair W. A., Lyon H. H., 2005. Diseases of trees and shrubs. Cornell Univ. Press. Ithaca.

S merl is E., 1970. Notes on Sydowia polyspora. Can. J. Bot. 48: 1613-1615.

Sutton B. C., Waterston J. M., 1970. Sydowia polyspora. CMI description of Pathogenic Fungi and Bacteria, 228.

Uotila A., Kurkela T., Tuomivirta T., Hantula J., Kaitera J., 2006. Gremmeniella abietina types cannot be distinguished using ascospore morphology. Forest Pathol. 36: 395-405. 
Wet de J., B urgess T., Slippers B., Preisig O., Wingfield B. D., Wing field M. J., 2003. Multiple gene genealogies and microsatellite markers reflect relationships between morphotypes of Sphaeropsis sapinea and distinguish a new species of Diplodia. Mycol. Res. 107: 557-566.

Zietkiewicz E., Rafalski A., Labuda D., 1994. Genome fingerprinting by simple sequence repeat (SSR) anchored polymerase chain reaction amplification. Genomics, 20: 176-183.
Zróżnicowanie i struktura genetyczna szczepów Sclerophoma pythiophila (Corda) v. Hoehn. związanych z różnymi typami objawów chorobowych i uszkodzeń na Pinus sylvestris L.

\section{Streszczenie}

Osiemdziesiąt trzy szczepy Sclerophoma pythiophila były izolowane w okresie 1996 - 2006 z igieł i pędów Pinus sylvestris wykazujących różne typy objawów chorobowych lub uszkodzeń spowodowanych przez Contarinia baeri lub Thecodiplosis brachyntera. Na podstawie 56 uzyskanych markerów RAMS stwierdzono bardzo wysokie zróżnicowanie genetyczne badanych szczepów (średnia wartość wsp. Jaccarda 0.58). Największe podobieństwo genetyczne wykazywały szczepy związane z uszkodzeniem igieł przez Contarinia baeri (0.65), natomiast najmniejsze pochodzące z zamarłych szczytów pędów (0.53). Nie stwierdzono monomorficznych dla poszczególnych grup szczepów markerów, jednak na podstawie macierzy odległości genetycznej Nei wyróżniono grupę blisko spokrewnionych populacji grzyba związanych z uszkodzeniem igieł przez C. baeri lub T. brachyntera (wsp. Nei od 0.035 do 0.059 ) oraz populacji związanych z występowaniem nekroz na pędach lub zamieraniem ich szczytów (wsp. Nei 0.066). Analiza PCA potwierdziła podobieństwo genetyczne szczepów związanych $\mathrm{z}$ uszkodzeniem igieł przez owady oraz szczepów izolowanych z lokalnych nekroz na pędach i zamarłych szczytów pędów. Wysoki stopień zróżnicowania genetycznego między populacjami wykazała analiza AMOVA. Stwierdzono duży (14.9\%), wysoce statystycznie istotny $(\mathrm{P}=0.001)$ udział miedzypopulacyjnej zmienności genetycznej. 